\title{
Composição botânica e química da Coastcross consorciada ou não com Arachis pintoi, com e sem nitrogênio
}

\author{
Botanical and chemical composition of Coastcross intercropped or not with "Arachis \\ pintoi", with and without nitrogen
}

\author{
RIBEIRO, Ossival Lolato ${ }^{1 *}$; CECATO, Ulysses ${ }^{2}$; RODRIGUES, Augusto Manoel $^{2}$; \\ FAVERI, Juliana Cantos ${ }^{3}$; SANTOS, Geraldo Tadeu dos ${ }^{2}$; LUGÃO, Simony Marta \\ Bernardo $^{4}$; BELONI, Tatiane ${ }^{5}$
}

\footnotetext{
${ }^{1}$ Universidade Federal da Bahia, Escola de Medicina Veterinária, Departamento de Produção Animal, Salvador, Bahia, Brasil.

${ }^{2}$ Universidade Estadual de Maringá, Centro de Ciências Agrárias, Departamento de Zootecnia, Maringá, Paraná, Brasil.

${ }^{3}$ Universidade Federal da Bahia, Escola de Medicina Veterinária, Programa de Pós Graduação em Ciência Animal nos Trópicos, Salvador, Bahia, Brasil.

${ }^{4}$ Instituto Agronômico do Paraná, Paranavaí, Paraná, Brasil.

${ }^{5}$ Universidade Estadual de Maringá, Centro de Ciências Agrárias, Programa de Pós Graduação em Zootecnia, Maringá, Paraná, Brasil.

*Endereço para correspondência: ossribeiro@yahoo.com.br
}

\section{RESUMO}

O objetivo com este trabalho foi avaliar a composição botânica e química do pasto de Coastcross + Arachis pintoi; Coastcross + Arachis pintoi com $100 \mathrm{~kg} /$ ha de nitrogênio $(\mathrm{N})$; Coastcross + Arachis pintoi com $200 \mathrm{~kg} / \mathrm{ha}$ de N; e Coastcross com $200 \mathrm{~kg} /$ ha de $\mathrm{N}$, nos períodos de inverno, primavera, verão e outono. Utilizou-se delineamento experimental em blocos ao acaso com os tratamentos em esquema de parcelas subdivididas, com duas repetições (blocos). Avaliou-se as percentagens de lâmina foliar verde, colmo+bainha verde, material morto e Arachis pintoi, bem como a razão folha/colmo (RF:C), além dos teores de proteína bruta, fibra em detergente neutro e digestibilidade in vitro da matéria seca. A utilização de $200 \mathrm{~kg} / \mathrm{ha}$ de $\mathrm{N}$ proporcionou a maior percentagem de lâmina foliar verde $(32 \%)$ e de colmo+bainha verde $(58 \%)$, porém com redução nas percentagens de material morto $(10 \%)$. No outono e no verão houve maiores percentagens de lâmina foliar e redução do material morto. Na primavera houve maior percentagem da leguminosa na massa de forragem. A adubação nitrogenada exclusiva ou associada ao Arachis pintoi aumentou os teores de proteína bruta e digestibilidade in vitro da matéria seca e reduziu o teor de fibra em detergente neutro da Coastcross. A associação entre leguminosa, adubação nitrogenada e condições climáticas favoráveis, proporciona melhor composição botânica e valor nutritivo do pasto consorciado.

Palavras-chave: adubação nitrogenada, amendoim forrageiro, lâmina foliar, proteína bruta, razão folha/colmo

\section{SUMMARY}

This study aimed to evaluate the botanical and chemical composition of pasture Coastcross + Arachis pintoi; Coastcross + Arachis pintoi with $100 \mathrm{~kg} /$ ha of nitrogen $(\mathrm{N})$; Coastcross + Arachis pintoi with $200 \mathrm{~kg} / \mathrm{ha} \mathrm{N}$, and Coastcross with $200 \mathrm{~kg} / \mathrm{ha} \mathrm{N}$, in the of winter, spring, summer and fall. The experimental design was randomized blocks with treatments in a splitplot with two replications (blocks). We evaluated the percentage of green leaf, stem green, dead material and Arachis pintoi as well as the ratio leaf / stem (RL: S), in addition to crude protein, neutral detergent fiber and in vitro digestibility dry matter. The use of $200 \mathrm{~kg} / \mathrm{ha} \mathrm{N}$ gave the highest percentages of leaf green $(32 \%)$ and stem + sheath green $(58 \%)$, but with a reduction in the percentage of dead 
material $(10 \%)$. In the autumn and summer there were higher percentages of leaf and reduced dead material. In the spring there was a higher percentage of legume in the forage mass. Nitrogen fertilization exclusively or associated with Arachis pintoi increased in vitro digestibility of dry matter and crude protein content and reduced content of Coastcross neutral detergent fiber. The association between legume nitrogen and favorable climatic conditions, provides improved botanical composition and nutritive value of pasture intercropping.

Keywords: crude protein, forage peanut, leaf blade, leaf/stem ratio, nitrogen fertilization

\section{INTRODUÇÃO}

Para almejar a máxima produção animal de forma sustentável e competitiva, a planta forrageira e os animais devem ser manejados de forma racional, conjuntamente, e deve-se encontrar o equilíbrio entre eles. A oferta de alimento de qualidade, no caso a planta forrageira, é de extrema importância para que o animal expresse todo seu potencial genético, por meio do rápido ganho de peso (RIBEIRO et al., 2011a). Assim, a avaliação da composição química das plantas forrageiras, por meio dos teores de proteína bruta, fibra em detergente neutro e digestibilidade in vitro da massa seca, é uma importante ferramenta na análise qualitativa do pasto, pois estes componentes podem influenciar, direta ou indiretamente, no consumo de forragem pelo animal e, consequentemente, no desempenho (LENZI et al., 2009a).

Outro fator importante na avaliação do pasto diz respeito à adubação, especialmente a nitrogenada. $O$ uso desta tecnologia é recomendável para aumentar a densidade da forragem e, sobretudo, a disponibilidade de folhas, observando-se incremento na produção da massa seca, principalmente em forrageiras com alto potencial de produção (PARIS et al., 2009a). Dentro deste contexto, Barbero et al. (2010) salientam que o nitrogênio melhora $o$ crescimento e a produção da planta, aumenta a participação de folhas, melhora sua qualidade por meio da elevação do teor de proteínas, e alimenta os microorganismos do solo que decompõem a matéria orgânica.

Além do nitrogênio introduzido via fertilizante, outra forma de fornecer nitrogênio para as gramíneas é por meio do uso de pastagens consorciadas com leguminosas. Muitos trabalhos de pesquisas em condições tropicais ressaltam a melhoria das pastagens em áreas de Coastcross consorciada com o Arachis pintoi (RIBEIRO et al., 2008; PARIS et al., 2009b; RIBEIRO et al., 2011b). Esta tecnologia é considerada ecologicamente recomendável, visto ser o nitrogênio introduzido na pastagem via fixação biológica e, portanto, menos poluente em comparação à adubação química (PARIS et al., 2008; LENZI et al., 2009b).

Bortolo et al. (2001) afirmam que a consorciação entre Coastcross e amendoim forrageiro é benéfica, pois ambas as forrageiras apresentam elevada produção de massa seca (MS) por área, boa adaptação ao clima subtropical, elevada relação folha/colmo e valor nutritivo. Assim, foi proposto o presente trabalho com o objetivo de avaliar a composição botânica e química do pasto de Coastcross consorciada ou não com Arachis pintoi, com e sem nitrogênio.

\section{MATERIAL E MÉTODOS}

O experimento foi conduzido na Estação Experimental do Instituto Agronômico do Paraná (IAPAR), em Paranavaí, noroeste do Paraná, 
Rev. Bras. Saúde Prod. Anim., Salvador, v.13, n.1, p.47-61 jan/mar, 2012 http://www.rbspa.ufba.br ISSN 15199940

localizado a $23^{\circ} 05^{\prime} \mathrm{S}$ e $42^{\circ} 26^{\prime} \mathrm{W}$ com $480 \mathrm{~m}$ de altitude. O tipo climático predominante na região é o Cfa - clima subtropical úmido mesotérmico, com predominância de verões quentes, baixa frequência de geadas severas e uma tendência de concentração das chuvas no período do verão. A temperatura média anual é de $22^{\circ} \mathrm{C}$, a média dos meses mais quentes (janeiro e fevereiro) é de $25^{\circ} \mathrm{C}$ e do mês mais frio (junho) $17,7^{\circ} \mathrm{C}$. A precipitação anual situa-se em torno de $1200 \mathrm{~mm}$. Os dados climatológicos referentes à precipitação, temperaturas máxima e mínima e radiação solar, ocorridos durante $\mathrm{o}$ período experimental, são apresentados na Tabela 1. O solo é classificado como Argissolo Vermelho distrófico (Avd), de textura arenosa, com aproximadamente $88 \%$ de areia, $2 \%$ de silte e $10 \%$ de argila (EMBRAPA, 2006), e sua composição química está exposta na Tabela 2.

Tabela 1. Dados climáticos observados durante o período experimental (julho de 2005 a junho de 2006)

\begin{tabular}{lcccc}
\hline \multirow{2}{*}{ Mês } & Temp. Máx. & Temp. Mín. & Precipitação Acumulada & Radiação Solar \\
\cline { 2 - 5 } & $\left({ }^{\circ} \mathrm{C}\right)^{*}$ & $\left({ }^{\circ} \mathrm{C}\right)^{*}$ & 57,4 & Cal/cm ${ }^{*} /$ dia $^{*}$ \\
\hline Junho & 23,7 & 13,3 & 15,6 & 252,6 \\
Agosto & 28,4 & 16,7 & 260,5 & 789,2 \\
Setembro & 24,4 & 14,1 & 228,1 & 757,6 \\
Outubro & 28,7 & 19,3 & 107,7 & 557,0 \\
Novembro & 30,3 & 19,1 & 63,3 & 430,1 \\
Dezembro & 30,6 & 19,8 & 147,9 & 896,9 \\
Janeiro & 32,2 & 21,6 & 208,1 & 382,7 \\
Fevereiro & 30,9 & 20,5 & 215,5 & 887,2 \\
Março & 31,0 & 21,0 & 45,5 & 342,1 \\
Abril & 28,4 & 17,8 & 17,8 & 290,7 \\
Maio & 25,0 & 12,9 & 33,1 & 277,6 \\
Junho & 25,7 & 14,8 & & 481,8 \\
\hline
\end{tabular}

*Média mensal

Fonte: Estação Meteorológica do Iapar - Paranavaí/PR, 2006.

Tabela 2. Resultado da análise de solo da área experimental $(0-20 \mathrm{~cm})$

\begin{tabular}{cccccccccccccc}
\hline \multirow{2}{*}{ Piquete } & $\mathrm{P}$ & $\mathrm{C}$ & $\mathrm{pH}$ & $\mathrm{Al}$ & $\mathrm{H}+\mathrm{Al}$ & $\mathrm{Ca}$ & $\mathrm{Mg}$ & $\mathrm{K}$ & $\mathrm{SB}$ & $\mathrm{CTC}$ & $\mathrm{V}$ & $\mathrm{m}$ \\
\cline { 2 - 13 } & \multicolumn{2}{c}{$\mathrm{mg} / \mathrm{dm}^{3}$} & $\mathrm{H}_{2} \mathrm{O}$ & \multicolumn{1}{c}{$\mathrm{cmol}_{\mathrm{d}} / \mathrm{dm}^{3}$} & & & $\%$ \\
\hline 1 & 7,53 & 7,50 & 4,60 & 0,16 & 3,49 & 0,82 & 0,59 & 0,13 & 1,58 & 5,03 & 30,18 & 10,18 \\
2 & 6,90 & 7,52 & 4,85 & 0,06 & 3,17 & 0,91 & 0,68 & 0,28 & 1,86 & 5,03 & 36,60 & 3,62 \\
3 & 9,60 & 7,16 & 4,50 & 0,15 & 3,43 & 0,81 & 0,48 & 0,22 & 1,50 & 4,93 & 30,19 & 9,99 \\
4 & 11,43 & 7,95 & 5,05 & 0,00 & 2,84 & 1,12 & 0,68 & 0,30 & 2,10 & 4,93 & 42,34 & 0,00 \\
5 & 11,40 & 7,18 & 4,63 & 0,10 & 3,30 & 0,83 & 0,45 & 0,29 & 1,56 & 4,86 & 31,98 & 5,66 \\
6 & 9,35 & 7,45 & 4,40 & 0,17 & 3,79 & 0,83 & 0,39 & 0,23 & 1,44 & 5,22 & 27,80 & 10,25 \\
7 & 10,38 & 8,32 & 4,78 & 0,06 & 3,30 & 0,78 & 0,59 & 0,24 & 1,61 & 4,90 & 32,63 & 3,60 \\
8 & 9,00 & 8,47 & 5,58 & 0,00 & 2,64 & 1,47 & 1,19 & 0,23 & 2,88 & 5,52 & 51,75 & 0,00 \\
\hline
\end{tabular}

Fonte: Laboratório de Solos do IAPAR - Londrina, 2005. 
O experimento foi conduzido no período de julho de 2005 a junho de 2006, o qual compreendeu as quatro estações (períodos) do ano. A área utilizada já estava estabelecida com piquetes contendo Coastcross exclusiva ou consorciada com amendoim forrageiro (Arachis Pintoi cv. Amarillo), compreendendo 5,3ha e dividida em oito piquetes (unidades experimentais), com área de 0,66ha cada, equipados com cochos para sal mineral e bebedouros.

No experimento utilizou-se delineamento experimental em blocos ao acaso com os tratamentos em esquema de parcelas subdivididas, com quatro repetições e compostos por quatro tratamentos (parcelas principais), a seguir descritos: $\mathrm{CAO}=$ Coastcross + Arachis pinto $;$; CA100 $=$ Coastcross + Arachis pinto com $100 \mathrm{~kg}$ por ha/ano de Nitrogênio; CA200 $=$ Coastcross + Arachis pintoi com 200kg por ha/ano de Nitrogênio; e $\mathrm{C} 200=$ Coastcross com $200 \mathrm{~kg}$ por ha/ano de Nitrogênio. $\mathrm{Na}$ subparcela, foram avaliados os períodos do ano: inverno (julho, agosto e setembro), primavera (outubro, novembro e dezembro), verão (janeiro, fevereiro e março) e outono (abril, maio e junho).

A adubação nitrogenada foi parcelada em quatro aplicações, a lanço, realizada em duas aplicações no período da primavera, $15 / 10 / 2005$ e $30 / 11 / 2005$, e duas no período do verão, 15/01/2006, 28/02/2006, e utilizou-se como fonte de nitrogênio o nitrato de amônio. As adubações potássica e fosfatada foram realizadas em duas aplicações, após a primeira e terceira parcela da adubação nitrogenada, mediante utilização do superfosfato simples e o cloreto de potássio como fonte de $\mathrm{P}$ e $\mathrm{K}$, respectivamente. As adubações de $\mathrm{P}$ e $\mathrm{K}$ foram realizadas com a finalidade de se fazer um nivelamento em seus níveis, nos tratamentos.
Para o manejo do pasto utilizou-se o método de lotação contínua com taxa de lotação variável, no qual utilizou-se uma oferta de forragem média de $6,6 \mathrm{~kg}$ de matéria seca (MS) para cada 100 de peso vivo (PV) animal, com disponibilidade de massa de forragem média de $1604 \mathrm{~kg} / \mathrm{ha}$ de MS. O ajuste da taxa de lotação foi realizado quando esta estava até 1,5 pontos percentuais acima ou abaixo da oferta de forragem pré-estabelecida $\quad(6 \mathrm{~kg}$ de $\mathrm{MS} / 100$ de PV). Os animais utilizados foram novilhas mestiças (Zebu x Europeu) com peso médio inicial de $170 \mathrm{~kg}$ de $\mathrm{PV}$, e usados três animais "testers" por piquete e animais reguladores, que foram colocados ou retirados, em função da disponibilidade de forragem, método "put-and-take" (MOTT \& LUCAS, 1952). Uma área adjacente à experimental, com a mesma gramínea forrageira (Coastcross exclusiva) estava à disposição para a manutenção dos animais reguladores. As taxas de lotação (TL) mensuradas durante $\mathrm{o}$ período experimental estão presentes na Tabela 3.

A composição botânica e química da pastagem foi avaliada pelo método da dupla amostragem descrito por Gardner (1986). Foram feitas 15 avaliações por piquete, a cada 28 dias, sendo 10 visuais e cinco cortadas ao nível do solo, por meio da utilização de um quadrado com área de $0,25 \mathrm{~m}^{2}(0,5 \times 0,5 \mathrm{~m})$. O material oriundo da coleta de estrato foi separado nas seguintes frações: lâmina foliar verde (LFV), colmo+bainha verde (BCV), material morto (MM) e Arachis pintoi (AP - planta inteira). Os materiais pertencentes às diferentes frações da planta foram secos em estufa à $55^{\circ} \mathrm{C}$ (ar forçado) por 72 horas e posteriormente pesados. 
Rev. Bras. Saúde Prod. Anim., Salvador, v.13, n.1, p.47-61 jan/mar, 2012 http://www.rbspa.ufba.br ISSN 15199940

Tabela 3. Média da taxa de lotação (TL) em pastagens de Coastcross em função dos tratamentos e estações do ano, durante o período de julho de 2005 a junho de 2006

\begin{tabular}{|c|c|c|c|c|c|}
\hline \multirow{3}{*}{ Tratamentos } & & Períod & Ano & & \multirow{3}{*}{ Média } \\
\hline & Inverno & Primavera & Verão & Outono & \\
\hline & \multicolumn{4}{|c|}{ TL (UA/dia) } & \\
\hline $\mathrm{CA}$ & 1,47 & 2,02 & 2,92 & 2,72 & 2,28 \\
\hline $\mathrm{CA}+100$ & 1,30 & 3,09 & 3,48 & 2,94 & 2,70 \\
\hline $\mathrm{CA}+200$ & 2,47 & 4,59 & 4,01 & 2,98 & 3,51 \\
\hline $\mathrm{C} 200$ & 2,18 & 3,92 & 4,01 & 2,94 & 3,26 \\
\hline Média* & 1,85 & 3,40 & 3,60 & 2,89 & - \\
\hline
\end{tabular}

$\mathrm{Na}$ composição botânica da pastagem, determinaram-se as percentagens de lâmina foliar verde, colmo+bainha verde, material morto e Arachis pintoi, bem como da determinação da razão folha/colmo (RFC). Na composição química, avaliaram-se os teores de proteína bruta $(\mathrm{PB})$, fibra em detergente neutro (FDN) e digestibilidade in vitro da massa seca (DIVMS). As amostras foram moídas em moinho tipo faca com peneira de $1 \mathrm{~mm}$ e acondicionadas em potes plásticos para as determinações dos teores de matéria seca definitiva através de estufa a $105^{\circ} \mathrm{C}$. Os teores de PB, FDN e DIVMS foram determinados segundo Silva \& Queiroz (2002), das frações descritas acima, exceto o material morto. Para determinação do teor de FDN foi utilizado o aparelho Fiber Analyser (ANKON).

Os tratamentos foram comparados, quanto às variáveis: percentagens de lâmina foliar verde, colmo+bainha verde, material morto e Arachis pintoi (planta inteira); Razão Folha/Colmo; teores de PB, FDN e DIVMS nas frações lâmina foliar verde e colmo+bainha verde, mediante utilização da ferramenta GLM (General Linear Model) que pertence ao programa SAS. As médias foram comparadas pelo teste de Tukey a $5 \%$ de probabilidade.

\section{RESULTADOS E DISCUSSÃO}

Não houve interação entre tratamentos principais e períodos do ano para a composição botânica do pasto de Coastcross $(\mathrm{P}>0,05)$. A percentagem de lâmina foliar verde foi mais elevada $(\mathrm{P}<0,05)$ no tratamento com $200 \mathrm{~kg} / \mathrm{ha}$ de $\mathrm{N}$ exclusivo e com amendoim forrageiro exclusivo sem adubação, enquanto que para colmo+bainha verde, as maiores percentagens foram obtidas nos tratamentos que se associa $200 \mathrm{~kg} / \mathrm{ha}$ de $\mathrm{N}$ com amendoim forrageiro e a gramínea exclusiva com $200 \mathrm{~kg} / \mathrm{ha}$ de $\mathrm{N}$ (Figura 1). Isto demonstra que a quantidade de $\mathrm{N}$ fixado pela leguminosa é suficiente para favorecer o crescimento da gramínea, porém, por meio do aumento na percentagem de lâminas foliares, pois o $\mathrm{N}$ é liberado gradativamente pela leguminosa, o que proporciona um crescimento mais uniforme da gramínea. No caso da associação entre leguminosa e adubação nitrogenada, esta também proporciona o crescimento da gramínea, no entanto, com o aumento da percentagem de colmo+bainha verde ocasionado pelo crescimento acelerado da gramínea, devido à maior quantidade de $\mathrm{N}$ 
Rev. Bras. Saúde Prod. Anim., Salvador, v.13, n.1, p.47-61 jan/mar, 2012 http://www.rbspa.ufba.br ISSN 15199940

prontamente disponível liberado pela adubação química.

Em relação à percentagem de material morto (Figura 1), observa-se que o aumento da adubação nitrogenada favoreceu a redução do material morto e, novamente, o tratamento com $200 \mathrm{~kg} / \mathrm{ha}$ de $\mathrm{N}$ apresentou o menor resultado $(\mathrm{P}<0,05)$, com menos material senescente, seguido do tratamento com $200 \mathrm{~kg} / \mathrm{ha}$ de $\mathrm{N}$ associado com amendoim forrageiro. Estes resultados podem ser explicados pela maior taxa de lotação utilizada nestes tratamentos (Tabela 3) que, embora tenham apresentado maior proporção de folhas e colmos, estes foram colhidos pelos animais, e assim evitou-se perdas por senescência (material morto). Estes resultados diferem de Paris et al. (2009b), que não observaram diferença entre tratamentos para esta variável em estudo realizado na mesma área experimental, com os mesmos tratamentos.

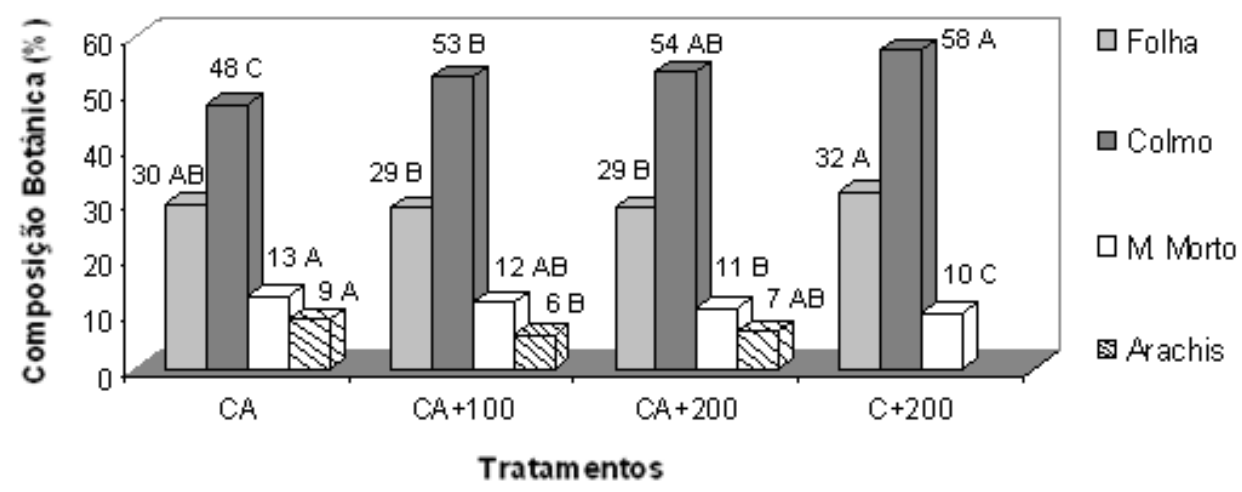

$* \mathrm{CA}=$ Coastcross + Arachis pinto $;$ CA100 $=$ Coastcross + Arachis pinto $+100 \mathrm{~kg} / \mathrm{ha}$ de $\mathrm{N} ; \mathrm{CA} 200=$ Coastcross + Arachis pintoi $+200 \mathrm{~kg} / \mathrm{ha}$ de N; C200 $=$ Coastcross + $200 \mathrm{~kg} / \mathrm{ha}$ de $\mathrm{N}$.

Figura 1. Médias das percentagens de lâmina foliar verde (LFV), colmo+bainha verde (CBV), material morto (MM) e Arachis pintoi (AP) em Coastcross em função dos tratamentos*

Para a percentagem de amendoim forrageiro (Figura 1), o tratamento com esta leguminosa exclusiva (Coastcross + Arachis pintoi) apresentou maior proporção $(\mathrm{P}<0,05)$ que os tratamentos com $\mathrm{N}+$ amendoim forrageiro $(100 \mathrm{~kg} / \mathrm{ha}$ de $\mathrm{N}$ ou $200 \mathrm{~kg} /$ ha de $\mathrm{N}+$ Arachis pintoi). Entretanto, os resultados evidenciam que a não aplicação de $\mathrm{N}$ no consórcio reduz o crescimento da gramínea (planta $\mathrm{C} 4$, de maior eficiência fotossintética), e assim favorece o crescimento da leguminosa (planta C3), o que proporciona aumento de produção de massa de forragem de leguminosa no acúmulo de massa de forragem total, além de favorecer a persistência da leguminosa no sistema produtivo. Este resultado pode propiciar o desempenho animal devido à maior participação da leguminosa na dieta animal, além de contribuir com a perenidade e produção da gramínea por meio da fixação biológica do N. Por outro lado, o uso do $\mathrm{N}$ no consórcio tem que ser melhor estudado, pois com essas quantidades relativamente altas aplicadas, a pastagem apresentou redução proporcional na massa de forragem da leguminosa na massa total de forragem. Resultado semelhante foi encontrado por 
Barbero et al. (2009) em estudo realizado na mesma área experimental, com os mesmos tratamentos.

Para composição botânica da pastagem nos períodos do ano (Figura 2), verificouse que a percentagem de lâmina foliar verde foi mais elevada $(\mathrm{P}<0,05)$ no outono, e superou o inverno, verão e primavera. Isto se explica em função de que na primavera, $\mathrm{o}$ pasto estava em plena recuperação após o inverno, portanto, apresentava menor produção de forragem e de massa de folha. No verão, as condições climatológicas permitiram maior crescimento da planta e, consequentemente, o aparecimento de folhas, que foi mantido durante o outono.

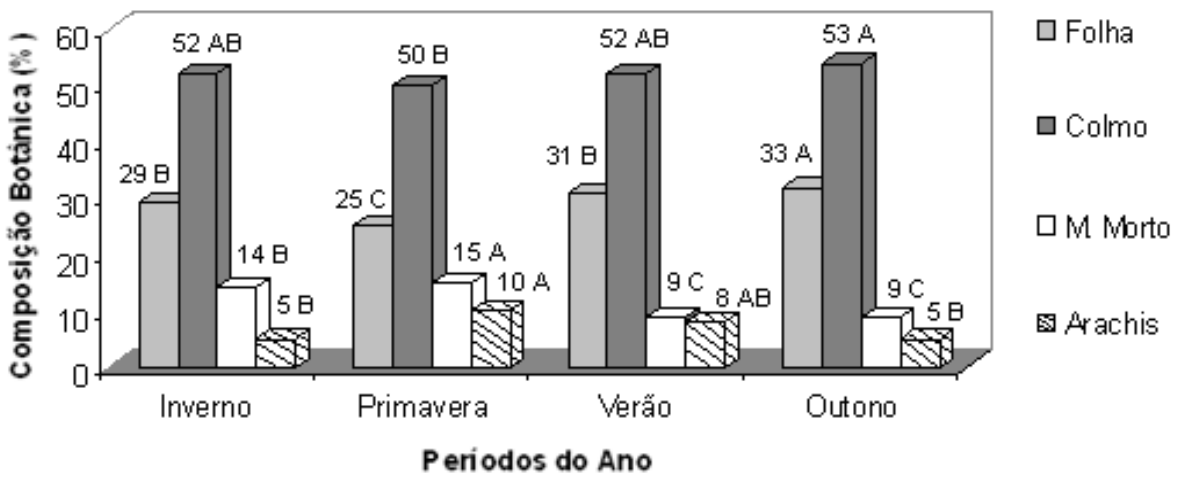

*Inverno $=$ julho/agosto/setembro/2005; Primavera $=$ outubro/novembro/dezembro/2005; Verão $=$ janeiro/fevereiro/ março/2006; Outono $=\mathrm{abril} / \mathrm{maio} / \mathrm{junho} / 2006$.

Figura 2. Médias das percentagens de lâmina foliar verde (LFV), colmo+bainha verde (CBV), material morto (MM) e Arachis pintoi (AP) em Coastcross em função do período do ano*

Estes resultados permitem inferir que, devido ao efeito residual da adubação nitrogenada que foi parcelada nos períodos de primavera e verão, houve produção de forragem mais bem distribuída nestes períodos do ano, onde as condições climáticas foram adequadas, o que favoreceu a produção de lâminas foliares no período do outono. Esta influência do manejo do pasto, a qual proporciona maior massa de forragem no período primavera-verão a fim de beneficiar a massa de forragem do outono foi relatada por Fagundes et al. (2005) e Basso et al. (2010).

A percentagem de colmo+bainha verde foi menor $(\mathrm{P}<0,05)$ na primavera do que no outono, porém este último, semelhante aos obtidos no verão e inverno. Isto pode ser justificado em função de que na primavera, o pasto está em plena recuperação após o inverno, portanto, apresenta menor produção de colmos, conforme se observou para lâminas foliares. Resultados semelhantes foram relatados por Fagundes et al. (2006), que ao trabalharem com Brachiaria decumbens fertilizada com $\mathrm{N}$ nas estações do ano, obtiveram menor percentagem de colmo no inverno-primavera, com elevação no período de verão-outono, independente da dose de $\mathrm{N}$ utilizada.

Em relação ao material morto, observase que na primavera a percentagem do mesmo foi maior $(\mathrm{P}<0,05)$ comparado aos demais períodos, o que evidencia a perda de material produzido (folha e colmo) por senescência, em função do 
acúmulo de material proveniente do inverno. A partir do verão, com melhorias nas condições climáticas, nota-se que houve uma redução e estabilização na percentagem de material morto, o que favoreceu o aumento nas percentagens de lâmina foliar verde e colmo+bainha verde. Resultado semelhante foi observado por Martha Junior et al. (2004) que quando trabalharam com capim-Tanzânia irrigado, sob diferentes intensidades de desfolha, obtiveram média de $28 \%$ e $14 \%$ de material morto para primavera e verão, respectivamente, independentemente dos tratamentos.

Para a percentagem de amendoim forrageiro (Figura 2), observa-se que esta foi maior $(\mathrm{P}<0,05)$ nos períodos de primavera e verão, respectivamente. Este resultado evidencia a necessidade de condições climatológicas favoráveis, principalmente a precipitação, para $\mathrm{o}$ bom desenvolvimento desta leguminosa. Segundo Nascimento (2006), precipitação anual superior a $1500 \mathrm{~mm}$ e secas inferiores a quatro meses são condições para o estabelecimento e uso desta espécie. Porém, no presente estudo, durante um ano de avaliação, registrou-se precipitação de $1400 \mathrm{~mm}$ (Tabela 1). Nestes períodos também realizou-se a adubação nitrogenada, o que demonstra que a associação entre o fornecimento de nitrogênio e precipitação adequada, proporciona condições ideais para a produção desta leguminosa.

Não houve interação entre tratamentos principais e períodos do ano para a razão folha:colmo (RF:C) do pasto de Coastcross $\quad(\mathrm{P}>0,05)$. Da mesma forma, não houve diferença $(\mathrm{P}>0,05)$ entre os tratamentos para a RF:C (Figura 3). Porém, observa-se que o uso do amendoim forrageiro exclusivo apresentou tendência $(\mathrm{P}<0,07)$ a maior $\mathrm{RF}: \mathrm{C}$. Este resultado é justificado, em parte, pelo equilíbrio da produção de lâminas foliares e colmo apresentado na Figura 1 neste tratamento. Cecato el al (2001), ao trabalharem com a mesma gramínea, com e sem adubação nitrogenada $(0$ e $400 \mathrm{~kg})$, obtiveram razão folha:colmo média de 0,74 e 0,90 , respectivamente, em 4 cortes durante o verão.

Para os períodos do ano (Figura 3), observa-se que não houve diferença $(\mathrm{P}>0,05)$ na $\mathrm{RF}: \mathrm{C}$ entre inverno, verão $\mathrm{e}$ outono, este foi mais baixo $(\mathrm{P}<0,05)$ na primavera. Este resultado pode ser explicado, em parte, pela aplicação de adubação nitrogenada, bem como pelo crescimento mais lento na fase inicial da primavera, e a maior presença de colmo maduros (mais pesados) remanescentes do inverno, no início e durante a primavera, o que contribuiu para a redução na RF:C neste período.

As concentrações de PB (Tabela 4), tanto para lâmina foliar verde (LFV) como para colmo+bainha verde (CBV) foram maiores $(\mathrm{P}<0,05)$ nos tratamentos que receberam $200 \mathrm{~kg} / \mathrm{ha}$ de $\mathrm{N}$ e as menores concentrações foram obtidas no tratamento com amendoim forrageiro exclusivo. Destaca-se que os valores foram relativamente elevados mesmo neste tratamento.

Geralmente, o uso de adubação nitrogenada tende a elevar o valor nutritivo da planta, principalmente pela elevação da quantidade de nitrogênio solúvel na forma orgânica e inorgânica (HERINGER \& JACQUES, 2002). Resultados semelhantes aos do presente estudo foram relatados por Paris et al (2008), em trabalhos realizados na mesma área experimental. Por outro lado, Rocha et al (2002) concluíram que o teor de proteína bruta foi influenciado apenas pelas doses de nitrogênio, pois à medida que houve aumento nas doses de nitrogênio, constataram aumentos consideráveis no teor médio de $\mathrm{PB}$, o que confirma os resultados obtidos no presente estudo. 
Rev. Bras. Saúde Prod. Anim., Salvador, v.13, n.1, p.47-61 jan/mar, 2012 http://www.rbspa.ufba.br ISSN 15199940
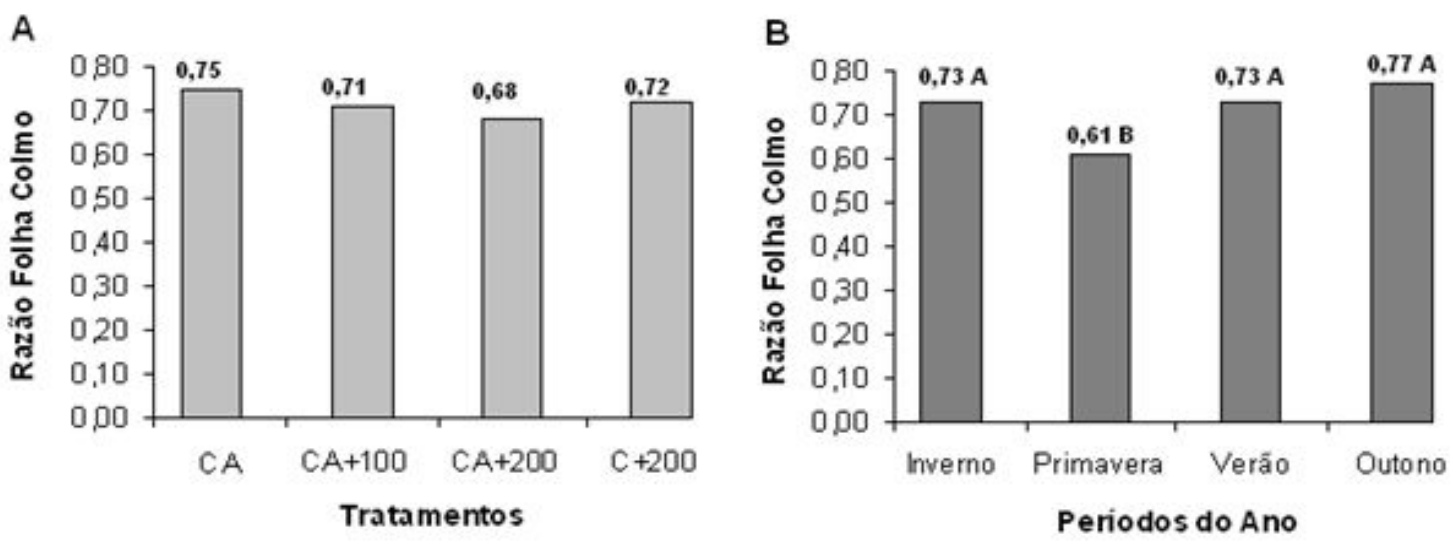

$* \mathrm{CA}=$ Coastcross + Arachis pinto $;$ CA100 $=$ Coastcross + Arachis pintoi $+100 \mathrm{~kg} / \mathrm{ha}$ de N; CA200 $=$ Coastcross + Arachis pintoi $+200 \mathrm{~kg} / \mathrm{ha}$ de N; C200 $=$ Coastcross $+200 \mathrm{~kg} / \mathrm{ha} \mathrm{de} \mathrm{N}$.

$* *$ Inverno $=$ julho/agosto/setembro/2005; Primavera $=$ outubro/novembro/dezembro/2005; Verão = janeiro/fevereiro/ março/2006; Outono = abril/ maio/ junho/2006.

Figura 3. Médias da razão folha:colmo em Coastcross em função dos tratamentos utilizados $(\mathrm{A})^{*}$ e dos períodos do ano $(\mathrm{B})^{* *}$

Tabela 4. Médias dos teores de proteína bruta (PB), fibra em detergente neutro (FDN) e digestibilidade in vitro da matéria seca (DIVMS) em Coastcross em função dos tratamentos

\begin{tabular}{lllllll}
\hline & \multicolumn{3}{c}{ Lâmina Foliar Verde* } & \multicolumn{3}{c}{ Colmo+Bainha Verde* } \\
\cline { 2 - 6 } Tratamento & PB & FDN & DIVMS & PB & FDN & DIVMS \\
\cline { 2 - 6 } & \multicolumn{5}{c}{$(\%)$} \\
\hline C A & $14,29^{\mathrm{C}}$ & $68,09^{\mathrm{A}}$ & $71,90^{\mathrm{B}}$ & $6,94^{\mathrm{C}}$ & $74,27^{\mathrm{A}}$ & $62,09^{\mathrm{B}}$ \\
C A 100 & $17,08^{\mathrm{B}}$ & $67,32^{\mathrm{AB}}$ & $73,20^{\mathrm{AB}}$ & $7,99^{\mathrm{B}}$ & $72,61^{\mathrm{B}}$ & $63,65^{\mathrm{AB}}$ \\
C A 200 & $18,36^{\mathrm{A}}$ & $66,20^{\mathrm{B}}$ & $73,71^{\mathrm{A}}$ & $8,56^{\mathrm{AB}}$ & $72,62^{\mathrm{B}}$ & $63,92^{\mathrm{A}}$ \\
C 200 & $18,32^{\mathrm{A}}$ & $66,75^{\mathrm{B}}$ & $74,41^{\mathrm{A}}$ & $9,28^{\mathrm{A}}$ & $72,68^{\mathrm{B}}$ & $64,78^{\mathrm{A}}$ \\
\hline Média & 17,01 & 67,09 & 73,30 & 8,19 & 73,04 & 63,61 \\
C.V. & 10,01 & 5,02 & 4,65 & 16,92 & 3,67 & 5,21 \\
\hline
\end{tabular}

*Letras diferentes na coluna diferem pelo teste de Tukey a $5 \%$ de probabilidade.

$\mathrm{CA}=$ Coastcross + Arachis pintoi $;$ CA100 $=$ Coastcross + Arachis pintoi $+100 \mathrm{~kg} / \mathrm{ha}$ de N; CA200 $=$ Coastcross + Arachis pintoi $+200 \mathrm{~kg} / \mathrm{ha} \mathrm{de} \mathrm{N} ; \mathrm{C} 200=$ Coastcross $+200 \mathrm{~kg} / \mathrm{ha} \mathrm{de} \mathrm{N}$.

Com relação os teores FDN (Tabela 4), observou-se o mesmo comportamento obtido para $\mathrm{PB}$, em que os tratamentos adubados apresentaram os menores teores de FDN, o que diferiu $(\mathrm{P}<0,05)$ do tratamento com amendoim forrageiro exclusivo, tanto para lâmina foliar verde quanto para colmo+bainha verde. Estes resultados corroboram com Brennecke
(2002), que afirma que uso de fertilizantes nitrogenados tende a reduzir o teor de carboidratos solúveis, e diminui assim o teor de carboidratos fibrosos. Rocha et al (2002), observaram que com o aumento das doses de nitrogênio ocorreu decréscimo nos teores de FDN da grama Coastcross. Segundo esse autor, redução no teor de FDN de capins do 
Rev. Bras. Saúde Prod. Anim., Salvador, v.13, n.1, p.47-61 jan/mar, 2012 http://www.rbspa.ufba.br ISSN 15199940

gênero Cynodon, em função do aumento de doses de nitrogênio, é observada com frequência na literatura. Estes decréscimos são desejáveis, pois, segundo Van Soest (1994), a redução da fibra na forragem vai possibilitar melhorias no consumo e na digestibilidade.

Semelhantemente à $\mathrm{PB}$ e FDN, a digestibilidade in vitro da massa seca (DIVMS) nos tratamentos adubados com $\mathrm{N}$, com ou sem a presença do amendoim forrageiro, foi maior $(\mathrm{P}<0,05)$ tanto para lâmina foliar verde quanto para colmo+bainha verde, que os tratamentos com amendoim forrageiro exclusivo (Tabela 4). Esses dados são superiores aos de Paris et al. (2008), que obtiveram DIVMS média de $63 \%$ e $54 \%$ para lâmina foliar verde e colmo+bainha verde. Estes resultados demonstram que a aplicação contínua de adubação nitrogenada pode melhorar a qualidade da pastagem, pois segundo Cecato et al (2001), quando se aduba as pastagens com nitrogênio, pode ocorrer uma variação na composição química da massa seca das plantas, onde o nitrogênio pode provocar um incremento no teor da PB e melhora na DIVMS, por meio do aumento da participação da massa seca de folhas na massa seca total da planta.

Os teores de $\mathrm{PB}$ nos períodos do ano (Tabela 5), para lâmina foliar verde foi maior $(\mathrm{P}<0,05)$ no outono que nos demais períodos. Este comportamento é explicado, em parte, pelas boas condições climatológicas ocorridas a partir da primavera (Tabela 1), que favoreceram a manutenção de uma boa qualidade de pastagem até o final do outono, pois neste período do ano, devido à menor luminosidade, precipitação e temperatura esperava-se uma redução na qualidade da forragem. Outra justificativa pode ser o efeito residual da adubação nitrogenada aplicada na primavera/verão, o que favorece a qualidade do pasto no outono. Estes resultados confirmam aqueles observados por Paris et al (2008). No colmo+bainha verde, os teores de PB foram maiores nos períodos de maior crescimento da planta (verão e outono).

Tabela 5. Teores de proteína bruta (PB), fibra em detergente neutro (FDN) e digestibilidade in vitro da matéria seca (DIVMS) em Coastcross em função dos períodos do ano

\begin{tabular}{lcccccc}
\hline \multirow{2}{*}{ Períodos } & \multicolumn{3}{c}{ Lâmina Foliar Verde* } & \multicolumn{3}{c}{ Colmo+Bainha Verde* } \\
\cline { 2 - 7 } & PB & FDN & DIVMS & PB & FDN & DIVMS \\
\cline { 2 - 7 } & \multicolumn{5}{c}{$(\%)$} \\
\hline Inverno & $16,07^{\mathrm{B}}$ & $65,65^{\mathrm{B}}$ & $71,59^{\mathrm{B}}$ & $7,16^{\mathrm{C}}$ & $73,99^{\mathrm{A}}$ & $61,55^{\mathrm{B}}$ \\
Primavera & $15,90^{\mathrm{B}}$ & $67,74^{\mathrm{A}}$ & $77,57^{\mathrm{A}}$ & $8,12^{\mathrm{B}}$ & $74,77^{\mathrm{A}}$ & $66,42^{\mathrm{A}}$ \\
Verão & $16,67^{\mathrm{B}}$ & $67,89^{\mathrm{A}}$ & $75,11^{\mathrm{A}}$ & $8,50^{\mathrm{AB}}$ & $71,36^{\mathrm{B}}$ & $64,94^{\mathrm{A}}$ \\
Outono & $19,39^{\mathrm{A}}$ & $67,07^{\mathrm{A}}$ & $68,97^{\mathrm{C}}$ & $8,99^{\mathrm{A}}$ & $72,05^{\mathrm{B}}$ & $61,54^{\mathrm{B}}$ \\
\hline Média & 17,01 & 67,09 & 73,31 & 8,19 & 73,04 & 63,61 \\
C.V. & 10,01 & 5,02 & 4,65 & 16,92 & 3,67 & 5,21 \\
\hline
\end{tabular}

*Letras diferentes na coluna diferem pelo teste de Tukey a $5 \%$ de probabilidade.

Inverno $=$ julho/agosto/setembro/2005; Primavera = outubro/novembro/dezembro/2005; Verão = janeiro/fevereiro/ março/2006; Outono $=$ abril/ maio/ junho/2006. 
O teor de FDN na lâmina foliar verde foi menor $(\mathrm{P}<0,05)$ no inverno, enquanto que a partir da primavera observou-se um pequeno aumento e a estabilização nos teores de FDN, sendo semelhantes entre os tratamentos. Com relação ao colmo+bainha verde, os teores de FDN foram inferiores $(\mathrm{P}<0,05)$ no verão e outono quando comparados ao inverno e primavera. Este resultado pode ser justificado, em parte, porque a partir da primavera ocorreu melhoria das condições climáticas (Tabela 1), o que favorece o aumento dos constituintes fibrosos da planta, e desse modo ocasiona o aumento nos teores de FDN da lâmina foliar verde e reduz os teores do colmo+bainha verde (Tabela 5). Em tempo, parte desta variação nos teores de FDN pode ser atribuída ao efeito da adubação nitrogenada, conforme justificativas supracitadas.

Para DIVMS, tanto para lâmina foliar verde quanto para colmo+bainha verde, esta foi maior $(\mathrm{P}<0,05)$ nos períodos da primavera e verão. Isto ocorreu devido às melhores condições de crescimento da planta forrageira nos períodos, em função das condições climáticas ocorridas. Estes resultados foram comprovados por Gonçalves et al (2002). Entretanto, os autores supracitados observaram uma interrelação entre a digestibilidade e os teores de $\mathrm{PB}$ e de parede celular, pois relatam que à medida que ocorre aumento nos teores de FDN e decréscimo na $\mathrm{PB}$, ocorre um declínio na digestibilidade, o que não se observou neste estudo. Por outro lado, os dados revelam que não existe uma relação positiva ou negativa entre FDN e DIVMS, haja vista que estes aumentaram concomitantemente no mesmo período, o que confirma os relatos feitos por Van Soest (1994) de que existe sim uma relação entre DIVMS e a fibra em detergente ácido (FDA) da forragem. A qualidade das gramas do gênero Cynodon, quando comparada a de outros capins tropicais tem mostrado superioridade em sua DIVMS. Os estudos que envolvem gramíneas desse gênero, a muito têm evidenciado que a Coastcross apresenta alta DIVMS, mesmo em idades avançadas, quando apresenta alta FDN (HILL et al, 1993).

A composição química da planta inteira do amendoim forrageiro (Tabela 6), não apresentou diferença $(\mathrm{P}>0,05)$ entre os tratamentos para PB, FDN e DIVMS. Paris et al. (2008) encontraram o teor médio PB, FDN e DIVMS com valores médios de $20 \% ; 50 \%$ e $63,4 \%$, em estudo na mesma área experimental. Neste contexto, deve-se destacar o elevado valor nutritivo dessa leguminosa, que se equipara às forrageiras de clima temperado (LADEIRA et al, 2002)

Para os períodos do ano (Tabela 6), observa-se que não houve diferença $(\mathrm{P}>0,05)$ para os teores de $\mathrm{FDN}$, que apresentou média de $43 \%$. No entanto, nota-se que durante $o$ verão, $o$ amendoim forrageiro apresentou os maiores valores $(\mathrm{P}<0,05)$ para $\mathrm{PB}$ e DIVMS em relação ao inverno, o que coincide com a melhor época de crescimento da pastagem, devido às condições climáticas, especialmente a pluviosidade, durante este período, além da adubação nitrogenada realizada na primavera e verão, o que pode ser verificado por meio da maior percentagem do amendoim forrageiro na pastagem (Figura 1 e 2). Estes resultados diferem dos relatados por Paris et al. (2008) que obtiveram teor médio de 50\% para FDN, 20\% para PB e $65 \%$ de DIVMS para o amendoim forrageiro. 
Rev. Bras. Saúde Prod. Anim., Salvador, v.13, n.1, p.47-61 jan/mar, 2012 http://www.rbspa.ufba.br ISSN 15199940

Tabela 6. Médias dos teores de proteína bruta (PB), fibra em detergente neutro (FDN) e digestibilidade in vitro da matéria seca (DIVMS) em planta inteira de Arachis pintoi em função dos tratamentos e períodos do ano

\begin{tabular}{lccc}
\hline \multirow{2}{*}{ Tratamento } & \multicolumn{3}{c}{ Arachis pintoi (planta inteira) } \\
\cline { 2 - 4 } & PB & FDN & DIVMS \\
\cline { 2 - 4 } & & $(\%)$ & \\
\hline C A & 17,35 & 42,46 & 79,06 \\
C A 100 & 17,16 & 42,92 & 79,64 \\
C A 200 & 17,06 & 43,78 & 80,08 \\
C 200 & - & - & - \\
\hline Média & 17,19 & 42,91 & 79,59 \\
C.V. & 8,65 & 4,93 & 2,74 \\
\hline Períodos & PB & FDN & $79,59^{\mathrm{B}}$ \\
& & $(\%)$ & $80,12^{\mathrm{B}}$ \\
\hline Inverno & $15,85^{\mathrm{C}}$ & 42,34 & $82,32^{\mathrm{A}}$ \\
Primavera & $17,75^{\mathrm{AB}}$ & 43,44 & $75,81^{\mathrm{C}}$ \\
Verão & $18,17^{\mathrm{A}}$ & 42,91 & 79,46 \\
Outono & $16,65^{\mathrm{BC}}$ & 43,23 & 2,74 \\
\hline Média & 17,10 & 43,00 & 4,93 \\
C.V. & 8,65 & \multicolumn{2}{c}{. }
\end{tabular}

*Letras diferentes na coluna diferem pelo teste de Tukey a 5\% de probabilidade.

$\mathrm{CA}=$ Coastcross + Arachis pintoi $;$ CA100 $=$ Coastcross + Arachis pinto $+100 \mathrm{~kg} / \mathrm{ha}$ de N; CA200 $=$ Coastcross + Arachis pintoi $+200 \mathrm{~kg} / \mathrm{ha} \mathrm{de} \mathrm{N}$; C200 $=$ Coastcross $+200 \mathrm{~kg} / \mathrm{ha} \mathrm{de} \mathrm{N}$.

Inverno $=$ julho/agosto/setembro/2005; Primavera $=$ outubro/novembro/dezembro/2005; Verão = janeiro/fevereiro/ março/2006; Outono = abril/ maio/ junho/2006.

Frente ao exposto, conclui-se que a utilização de adubação nitrogenada exclusiva, proporciona maiores percentagens de lâmina foliar verde e de colmo+bainha verde, porém com redução nas percentagens de material morto da grama Coastcross. A utilização da adubação nitrogenada na grama Coastcross em consorciação reduziu a percentagem do amendoim forrageiro na massa de forragem. Ainda, a utilização de leguminosa e adubação nitrogenada não alteram a razão folha colmo do pasto. Por fim, a adubação nitrogenada associada ao amendoim forrageiro melhorou o valor nutritivo da Coastcross, tanto a pastagem consorciada quanto o amendoim forrageiro apresentam bom valor nutritivo.

\section{REFERÊNCIAS}

BARBERO, L.M.; CECATO, U.; LUGÃO, S.M.B.; GOMES, J.A.N.; LIMÃO, V.A.; ABRAHÃO, J.J.S.; ROMA, C.F.C. Produção animal e valor nutritivo da forragem de pastagem de coastcross consorciada com amendoim forrageiro. Arquivo Brasileiro de Medicina Veterinária e Zootecnia, v.62, n.3, p.645-653, 2010.

BARBERO, L.M.; CECATO, U.; LUGÃO, S.M.B.; GOMES, J.A.N.; LIMÃO, V.A.; BASSO, K.C. Produção de forragem e componentes morfológicos em pastagem de coastcross consorciada com amendoim forrageiro. Revista Brasileira de

Zootecnia, v.38, n.5, p.788-795, 2009. 
Rev. Bras. Saúde Prod. Anim., Salvador, v.13, n.1, p.47-61 jan/mar, 2012 http://www.rbspa.ufba.br ISSN 15199940

BASSO, K.C.; CECATO, U.; LUGÃO, S.M.B.; GOMES, J.A.N.; BARBERO, L.M.; MOURÃO, G.B. Morfogênese e dinâmica do perfilhamento em pastos de Panicum maximum Jacq. cv. IPR-86 Milênio submetido a doses de nitrogênio. Revista Brasileira de Saúde e Produção Animal [Online], v.11, n.4, p.976-989, 2010.

BORTOLO, M.; CECATO, U.; MACEDO, F.A.F. Desempenho de Ovelhas, Composição Química e Digestibilidade in Vitro em uma Pastagem de Coastcross-1 (Cynodon dactylon (L.) Pers) sob Diferentes Níveis de Matéria Seca Residual. Revista Brasileira de Zootecnia, v.30, n.3, p.636-643, 2001.

BRENNECKE, K. Efeitos de doses de sódio e nitrogênio na composição bromatológica, química $\mathrm{e}$ digestibilidade in vitro do capimcoastcross (Cynodon dactylon (L.) Pers.), em duas idades de corte. 2002. 73p. Dissertação (Mestrado) -Faculdade de Zootecnia e Engenharia de

Alimentos, Universidade de São Paulo, Pirassununga.

CECATO, U.; CANO, C.C.P.; BORTOLO, M.; HERLING, V.R.; CANTO, M.W.; CASTRO, C.R.C. Teores de Carboidratos Não-Estruturais, Nitrogênio Total e Peso de Raízes em Coastcross-1 (Cynodon dactylon (L.) Pers) Pastejado por Ovinos. Revista Brasileira de Zootecnia, v.30, n.3, p.644-650, 2001.

EMPRESA BRASILEIRA DE PESQUISA AGROPECUÁRIA EMBRAPA. Sistema brasileiro de classificação de solos. 2.ed. Rio de Janeiro, 2006. 306p.
FAGUNDES, J.L.; FONSECA, D.M.; MISTURA, C.; MORAIS, R.V.; VITOR, C.M.T.; GOMIDE, J.A.; NASCIMENTO JUNIOR, D.; CASAGRANDE, D.R.; COSTA, L.T. Características morfogênicas e estruturais do capim-braquiária em pastagem adubada com nitrogênio avaliadas nas quatro estações do ano.

Revista Brasileira de Zootecnia, v.35, n.1, p.21-29, 2006.

FAGUNDES, J.L.; FONSECA, D.M.; GOMIDE, J.A.; NASCIMENTO

JUNIOR, D.; VITOR, C.M.T.;

MORAIS, R.V.; MISTURA, C.; REIS, G.C.; MARTUSCELLO, J.A. Acúmulo de forragem em pastos de Brachiaria decumbens adubados com nitrogênio.

Pesquisa Agropecuária Brasileira, v.40, n.4, p.397-403, 2005.

GARDNER, A.L. Técnicas de pesquisa em pastagens $e$ aplicabilidade de resultados em sistemas de produção. Brasília: IICA, 1986. 197p.

GONÇALVES, G.D.; SANTOS, G.T.; CECATO, U.; JOBIM, C.C.; DAMASCENO, J.C.; BRANCO, A.F.; FARIA, K.P. Produção e valor nutritivo de gramíneas do gênero Cynodon em diferentes idades ao corte durante o ano. Acta Scientiarum, v.24, n.4, p.11631174, 2002.

HERINGER, I.; JACQUES, A.V.Á. Qualidade da forragem de pastagem nativa sob distintas alternativas de manejo. Pesquisa Agropecuária Brasileira, v.37, n.3, p.399-406, 2002.

HILL, G.M.; GATES, R.N.; BURTON, G.W. Forage quality and grazing steer performance from Tifton 85 and Tifton 78 bermudagrass pastures. Journal Animal Science, v.71, p.3219-3225, 1993. 
Rev. Bras. Saúde Prod. Anim., Salvador, v.13, n.1, p.47-61 jan/mar, 2012 http://www.rbspa.ufba.br ISSN 15199940

LADEIRA, M.M.; RODRIGUEZ, N. M.; BORGES, I.; GONÇALVES, L.C.; SALIBA, E.O.S.; BRITO, S.C.; SÁ, L.A.P. Avaliação de feno de Arachis pintoi utilizando o ensaio de disgestibilidade in vivo. Revista Brasileira de Zootecnia, v.31, p.23502356, 2002.

LENZI, A.; CECATO, U.; MACHADO FILHO, L.C.P.; GASPARINO, E.; ROMA, C.F.C.; BARBERO, L.M.; LIMÃO, V.A.. Produção e qualidade do pasto de coastcross consorciado ou não com amendoim forrageiro com ou sem aplicação de nitrogênio. Arquivo Brasileiro de Medicina Veterinária e Zootecnia, v.61, n.4, p.918-926, 2009a.

LENZI, A.; CECATO, U.; MACHADO FILHO, L.C.P.; SILVA, M.A.G.; GASPARINO, E.; ROMA, C.; BARBERO, L. Dinâmica do n-mineral em pastagem de coastcross consorciado com Arachis pintoi com ou sem nitrogênio em duas estações do ano.

Revista Brasileira de Agroecologia, v.4, n.1, p.51-58, 2009 b.

MARTHA JUNIOR, G.B.; CORSI, M.; BARIONI, L.G.; VILELA, L.. Intensidade de desfolha e produção de forragem do capim-tanzânia irrigado na primavera e no verão. Pesquisa Agropecuária Brasileira, v.39, n.9, p.927-936, 2004.

MOTT, G.O.; LUCAS, H.L. The design, conduct and interpretation of grazing trials on cultivated and improved pastures. In: International Grassland Congress, 6, 1952, Pasadena. Proceedings... Pasadena, 1952. p.13801385.

NASCIMENTO, I.S. O cultivo do amendoim forrageiro. Revista

Brasileira de Agrociência, v.12, n.4, p.387-393, 2006.
PARIS, W.; CECATO, U.; BRANCO, A.F.; BARBERO, L.M.; GALBEIRO, S. Produção de novilhas de corte em pastagem de Coastcross-1 consorciada com Arachis pintoi com e sem adubação nitrogenada. Revista Brasileira de Zootecnia, v.38, n.1, p.122-129, 2009a.

PARIS, W.; CECATO, U.; MARTINS, E.N.; LIMÃO, V.A.; GALBEIRO, S.; OLIVEIRA, E. Estrutura e valor nutritivo da pastagem de Coastcross -1 consorciada com Arachis pintoi, com e sem adubação nitrogenada. Revista

Brasileira de Saúde e Produção Animal [Online], v.10, n.3, p.513-524, 2009b.

PARIS, W.; CECATO, U.;SANTOS, G.T.; BARBERO, L.; AVANZZI, L.; LIMÃO, A. Produção e qualidade de massa de forragem nos estratos da cultivar Coastcross-1 consorciada com Arachis pintoi com e sem adubação nitrogenada. Acta Scientiarum.

Animal Sciences, v.30, n.2, p.135-143, 2008.

RIBEIRO, O.L.; CECATO, U.; IWAMOTO, B.S.; PINHEIRO, A.; JOBIM, C.C.; DAMASCENO, J.C. Desempenho de bovinos em capimTanzânia adubado com nitrogênio ou consorciado com Estilosantes. Revista Brasileira de Saúde e Produção Animal [Online], v.12, n.1, p.275-285, $2011 \mathrm{a}$.

RIBEIRO, O.L.; CECATO, U.;RODRIGUES, A.M.; FAVERI, J.C.; JOBIM, C.C.; LUGÃO, S.M.B.

Biomassa radicular e reservas orgânicas em Coastcross consorciada ou não com "Arachis pintoi", com e sem nitrogênio, sob pastejo. Revista Brasileira de Saúde e Produção Animal [Online], v.12, n.2, p.318-328, 2011 b. 
Rev. Bras. Saúde Prod. Anim., Salvador, v.13, n.1, p.47-61 jan/mar, 2012 http://www.rbspa.ufba.br ISSN 15199940

RIBEIRO, O.L.; CECATO, U.; ROMA, C.F.C; FAVERI, J.C.; GOMES, J.A.N.; BARBERO, L.M. Produção de forragem e desempenho animal em pastagens de Coastcross consorciada ou não com Arachis pintoi, com e sem nitrogênio. Acta Scientiarum. Animal Sciences, v.30, n.4, p.371-377, 2008.

ROCHA, G.P.; EVANGELISTA, A.R.; LIMA, J.A.; ROSA, B. Adubação Nitrogenada Em Gramíneas Do Gênero Cynodon. Ciência Animal Brasileira, v.3, n.1, p.1-9, 2002.
SILVA, D.J.; QUEIROZ, A.C. Análise de alimentos: métodos químicos e biológicos. 3.ed. Viçosa, MG:

Universidade Federal de Viçosa, 2002. 235p.

VAN SOEST, P. J. Nutricional ecology of the ruminant. 2.ed. New York: Cornell University Press, 1994.

Data de recebimento: 16/08/2011

Data de aprovação: 31/01/2012 